\title{
PENGENDALIAN BAHAYA KERJA DENGAN METODE JOB SAFETY ANALYSIS PADA PENERIMAAN AFVAL LOKAL BAGIAN WAREHOUSE DI PT. ST
}

\author{
Nurkholis $^{1}$, Gusti Adriansyah ${ }^{2}$ \\ 1,2Teknik Industri, Fakultas Teknik \\ Universitas Maarif Hasyim Latif, Sidoarjo, Indonesia \\ e-mail : ${ }^{1}$ nurkholis1024@gmail.com, ${ }^{2}$ gustiadriansyah@yahoo.com \\ Diterima: 17 Maret 2017. Disetujui : 16 Mei 2017. Dipublikasikan : 1 Juni 2017 \\ (C)2017 -TESJ Fakultas Teknik Universitas Maarif Hasyim Latif. Ini adalah artikel dengan \\ akses terbuka di bawah lisensi CC BY 4.0 (https://creativecommons.org/licenses/by/4.0/)
}

\begin{abstract}
ABSTRAK
Job Safety Analysis (USA) adalah suatu kajian sistematis dan bertahap terhadap semua potensi kejadian berbahaya yang terdapat di tiap langkah kerja, untuk dapat menentukan berbagai tindakan pengendalian yang dibutuhkan untuk mencegah atau mengurangi dampak dari kejadian berbahaya tersebut, selama proses persiapan dan pelaksanaan suatu pekerjaan (Chevron, 2005). Seperti pada penerimaan afval lokal bagian warehouse di PT. ST adalah suatu perusahaan yang berjalan di bidang pembuatan kertas yang bertempat di Surabaya, Jawa timur, yang memiliki potensi bahaya yang dapat menyebabkan kecelakaan kerja.

Dengan adanya implementasi program K3 akan sangat membantu dalam menangani permasalahan tersebut, salah satu program K3 adalah melakukan identifikasi jenis kecelakaan kerja dan upaya pencegahan kecelakaan kerja dengan menggunakan metode Job Safety Analysis.

Berdasarkan hasil penelitian yang dilakukan dengan menggunakan metode $J S A$ dapat diidentifikasi jenis kecelakaan kerja/potensi bahaya yang berhubungan dari setiap langkah pekerjaan pada penerimaan afval lokal yaitu : terjatuh dari atas kendaraan, tertimpah bal-balan kertas, terjepit oleh bal-balan kertas, terjepit tali bal-balan, terkena cutter, terkena plat atau kawat, tertabrak kendaraan dan terpeleset atau terkilir. Dan jenis kecelakaan kerja yang dominan pada penerimaan afval lokal adalah terkena cutter. Dari perhitungan angka kecelakaan, maka dapat diketahui tingkat kecelakaan kerja dari tahun 2013 sampai tahun 2015 adalah turun yang berarti kinerja pada penerimaan afval lokal naik. Rekomendasi pencegahan kecelakaan kerja pada penerimaan afval lokal sebagai berikut : baca/ikuti ramburambu keselamatan, mengikuti briffing sebelum kerja, mengikuti instruksi kerja yang benar, gunakan sarung tangan katun dan gunakan sepatu.
\end{abstract}

Kata kunci : Job Safety Analysis, keselamatan dan kesehatan kerja, pengendalian bahaya kerja

\section{PENDAHULUAN}

Dari hasil penelusuran kecelakaan kerja $d$ PT. ST dirasakan masih cukup tinggi, dimana hal ini dapat dilihat dari data di PT. ST yaitu : data jumlah kecelakaan kerja selama kurang lebih 3 tahun sebanyak 37 kecelakaan. Data ini meliputi kecelakaan kerja yang terjadi pada penerimaan afval lokal bagian warehouse, dimana karyawan mengalami kecelakaan kerja saat pembongkaran afval lokal. Afval lokal tadi dikirim oleh supplier dengan menggunakan kendaraan seperti : pick up, colt diesel, fuso, tronton, wing box, countener dan gandengan. Pengebalan afval lokal itu menggunakan tali rafia, tali nilon, tali straffing, kawat dan plat sehingga pada proses pembongkaran afval lokal, pekerja bongkar terkena cutter dan jatuh dari kendaraan. Data di atas menunjukkan masih tingginya tingkat kecelakaan kerja yang terjadi. Data tersebut belum bisa mewakili jumlah kecelakaan kerja yang sebenarnya terjadi karena banyaknya kasus kecelakaan kerja tidak dilaporkan yang jumlahnya diperkirakan lebih banyak lagi.

Dalam lingkungan industri khususnya di PT. ST, berbagai potensi bahaya misalnya bahaya kejatuhan bal-balan afval lokal yang menyebabkan karyawan terluka, senantiasa dijumpai, serta belum terukurnya secara lengkap potensi bahaya (hazard) adalah problematika yang ada di perusahaan tersebut. Cara yang dapat dilakukan adalah menerapkan dan mengukur tingkat keberhasilan program Keselamatan dan Kesehatan Kerja (K3) untuk mengkategorikan hazard dengan menggunakan metode Job Safety Analysis yang ditentukan berdasar pada parameter banyaknya kecelakaan yang terjadi. Dari hasil pengukuran tersebut akan memberi gambaran mengenai tingkat implementasi program K3 dan rekomendasi atau saran mengenai kekurangan yang perlu diperbaiki atau keberhasilan yang perlu dipertahankan dan lebih ditingkatkan. Dengan 
informasi ini dapat diketahui hazard (potensi bahaya) yang mempunyai nilai resiko paling tinggi (high risk) sampai hazard yang mempunyai nilai resiko paling rendah (low risk). Dengan demikian dapat dilakukan penanganan yang tepat sebagai usaha untuk mencegah terjadinya kecelakaan kerja dikemudian hari.

\section{METODE PENELITIAN}

Job Safety Analysis (JSA) adalah berupa pemeriksaan prosedural untuk menentukan apakah prosedur yang tengah dijalankan telah berjalan sebagaimana mestinya, dan untuk memeriksa aspekaspek sikap dari orang-orang yang melaksanakan pekerjaan dimaksud (Alkon, 2004). Poin utama dari job safety analysis adalah mencegah kecelakaan dengan antisipasi dan eliminasi serta mengontrol bahaya yang ada (KI, 2012). JSA merupakan salah satu langkah utama dalam analisa bahaya dan kecelakaan dalam usaha menciptakan keselamatan kerja. Bila bahaya telah dikenali maka dapat dilakukan tindakan pengendalian yang berupa perubahan fisik atau perbaikan prosedur kerja yang dapat mereduksi bahaya kerja. Dalam pelaksanaannya, prosedur analisa keselamatan kerja memerlukan latihan, pengawasan dan penulisan uraian kerja yang dikenal sebagai JSA untuk mempermudah pengertian prosedur kerja pada karyawan.

Dalam melakukan analisa potensi bahaya pekerjaan dengan menggunakan Job Safety Analysis ada empat langkah dasar yaitu :

1. Menentukan pekerjaan yang akan dianalisa.

2. Menguraikan pekerjaan menjadi langkah-langkah dasar.

3. Mengidentifikasi bahaya atau kecelakaan kerja pada masing-masing pekerjaan.

4. Mengendalikan bahaya dalam upaya pencegahan kecelakaan kerja.

Proses selanjutnya adalah melakukan analisis dengan memperhatikan empat langkah dasar di atas serta penggunaan format tabel dan rumusan untuk membantu teknik analisisnya dengan uraian sebagai berikut:

\section{Analisis jenis kecelakaan kerja}

Jenis kecelakaan kerja dianalisis dengan melakukan observasi atau pengamatan langsung terhadap proses kerja penerimaan afval lokal dan melakukan wawancara kepada karyawan yang bersangkutan untuk mendapatkan informasi tentang jenis kecelakaan kerja yang terjadi, di bagian mana, serta kapan saat terjadinya kecelakaan kerja tersebut dalam rentang waktu tertentu.

\section{Analisis data frekuensi kecelakaan kerja}

Data frekuensi kecelakaan kerja dianalisis dengan klasifikasi menurut jenis kecelakaan menunjukkan peristiwa yang langsung mengakibatkan kecelakaan kerja. Frekuensi kecelakaan kerja merupakan unsur penting untuk merencanakan langkah-langkah pencegahan kecelakaan serta untuk menilai produktivitas. Dari data ini dapat diketahui berapa banyak kecelakaan kerja yang terjadi dalam rentang waktu tertentu.

Frequency Rate (FR; tingkat frekuensi) digunakan untuk mengetahui frekuensi angka kecelakaan dalam satu juta jam kerja untuk kurun waktu tertentu dari tahun ke tahun. Hal ini dapat dilakukan dengan menghitung angka frekuensi kecelakaan (F), yaitu banyaknya kecelakaan untuk setiap juta jam kerja orang yang dapat diukur dengan rumus statistik kecelakaan persamaan (1).

Frekuensi kecelakaan kerja (FR)

$$
=\frac{\text { Banyaknya kecelakaan } \times 1.000 .000}{\text { Jam kerja orang }}
$$

Severity Rate (SR; tingkat berat/keparahan) adalah suatu angka yang menunjukkan jumlah jam yang hilang disebabkan terjadinya kecelakaan/cedera kerja dalam 1.000.000 jam dalam kurun waktu tertentu, digunakan untuk menentukan tingkat hari kerja yang hilang karena kecelakaan kerja. Untuk mengukur pengaruh kecelakaan, juga harus dihitung angka beratnya kecelakaan. Angka beratnya kecelakaan (S) adalah jumlah total hilangnya hari kerja per 1.000 .000 jam kerja yang dapat diukur dengan rumus statistik persamaan (2).

$$
\begin{aligned}
\text { Beratnya kecelakaan }(S R) & \\
& =\frac{\text { Jumlah hilangnya jam kerja } \times 1.000 .000}{\text { Jam kerja orang }}
\end{aligned}
$$

Angka frekuensi kecelakaan (FR) dan angka keparahan atau beratnya kecelakaan (SR) dapat diubah menjadi satu indicator FSI (Frequency Severity Indicator) sebagaimana diterangkan di atas dengan rumus persamaan (3).

Tingkat keadaan (FSI)

$$
=\frac{\text { Frequency Rate } x \text { Severity Rate }}{1000}
$$

Nilai FSI ini dapat dijadikan rangking kinerja antar bagian di tempat kerja yang menunjukkan naikturunnya kinerja.

\section{Analisis data jenis kecelakaan kerja yang dominan}

Data jenis kecelakaan kerja yang dominan dianalisis dengan cara mencari jumlah dan tipe kecelakaan yang terjadi dalam kurun waktu tertentu, serta mendapatkan informasi tentang penyebab kecelakaan kerja tersebut, baik dari sisi pelaksanaan pekerjaan yang berpotensi bahaya, serta dari sisi kondisi kerja yang kurang memadai.

\section{Upaya Pencegahan Kecelakaan Kerja}


Upaya pencegahan kecelakaan kerja dilakukan dengan menggunakan metode Job Safety Analysis pada penerimaan afval lokal sebagai berikut:

1. Memilih pekerjaan/job yang akan dianalisa, dengan mempertimbangkan :

a. Berdasarkan jenis kecelakaan kerja

b. Berdasarkan jenis kecelakaan kerja yang dominan

c. Berdasarkan upaya pencegahan kecelakaan kerja

2. Memecah pekerjaan/job atas beberapa langkah kerja. Pekerjaan yang dipilih untuk dianalisa, dipecah atas beberapa langkah kerja sedemikian rupa yang dapat menunjukkan apa yang dikerjakan dan dalam urutan yang keberapa.

3. Mengidentifikasi bahaya atau kecelakaan kerja yang dominan. Setiap langkah dipelajari akan adanya bahaya atau kecelakaan kerja yaitu dengan cara mengamati langkah kerja dan mencari kemungkinan adanya kecelakaan kerja yang dominan.

4. Membuat pemecahan atau jalan keluar untuk mencegah kecelakaan kerja. Membuat pemecahan atau jalan keluar untuk mencegah kecelakaan kerja seperti mencegah supaya pekerja tidak terkena cutter maka pemecahan penanggulangan kecelakaan dapat dilakukan dengan cara :

a. Pekerja diberikan bimbingan dengan aturan cara kerja penggunaan cutter yang baik dan benar

b. Pekerja diberikan keahlian atau ketrampilan dalam penggunaan cutter yang baik dan benar

c. Pekerja diberikan bimbingan dan pengetahuan yang baik untuk pembongkaran afval lokal dengan menggunakan cutter

d. Pekerja diberikan bimbingan untuk bersikap waspada dan berhati-hati dalam penggunaan cutter

\section{HASIL DAN PEMBAHASAN}

Langkah pertama dalam pembuatan Job Safety Analysis di PT. ST adalah menentukan pekerjaan yang akan dianalisa. Pekerjaan yang akan dianalisa adalah pekerjaan pada penerimaan afval lokal yang meliputi : kertas box, koran, duplex, hvs, wpt dan kertas cd. Berikut ini adalah data kecelakaan kerja hasil rekapitulasi pada penerimaan afval lokal:

Tabel 1. Data kecelakaan kerja

\begin{tabular}{|c|c|c|c|c|c|c|}
\hline \multirow{2}{*}{ Tahun } & \multicolumn{3}{|c|}{ Checker } & \multicolumn{2}{c|}{ Quality assurance } & \multicolumn{2}{c|}{ Pekerja Bongkar } \\
\cline { 2 - 7 } & Pekerja & Kecelakaan & Pekerja & Kecelakaan & Pekerja & Kecelakaan \\
\hline 2013 & 14 & 2 & 7 & 1 & 28 & 14 \\
\hline 2014 & 14 & 1 & 7 & 1 & 28 & 10 \\
\hline 2015 & 14 & 1 & 7 & 0 & 28 & 6 \\
\hline
\end{tabular}

Dari Tabel 1 dapat disimpulkan bahwa tinggirendahnya suatu kecelakaan di tempat kerja sangat dipengaruhi oleh sedikit-banyaknya pekerja yang bekerja di tempat kerja tersebut. Semakin sedikit pekerja yang bekerja di tempat kerja maka akan semakin rendah pula tingkat kecelakaan di tempat kerja maupun paparan terhadap bahaya di tempat kerja yang menjadi penyebabnya. Begitupun juga sebaliknya, semakin banyak pekerja yang bekerja di tempat kerja maka akan semakin tinggi pula tingkat kecelakaan di tempat kerja maupun paparan terhadap bahaya di tempat kerja yang menjadi penyebabnya.

Dari data kecelakaan kerja pada masing-masing bagian untuk periode tiga tahun ini kemudian diolah untuk mendapatkan data mengenai jenis kecelakaan dan frekuensinya.

Tabel 2. Jenis kecelakaan kerja

\begin{tabular}{|c|l|c|}
\hline NO. & \multicolumn{1}{|l|}{ JENIS KECELAKAAN KERJA } & FREKUENSI \\
\hline $\mathbf{1}$ & Terjatuh dari atas kendaraan & $\mathbf{3}$ \\
\hline $\mathbf{2}$ & Tertimpah bal-balan kertas & $\mathbf{3}$ \\
\hline $\mathbf{3}$ & Terjepit oleh bal-balan kertas & $\mathbf{2}$ \\
\hline $\mathbf{4}$ & Terjepit tali bal - balan & $\mathbf{1}$ \\
\hline $\mathbf{5}$ & Terkena cutter & $\mathbf{2 4}$ \\
\hline $\mathbf{6}$ & Terkena plat atau kawat & $\mathbf{2}$ \\
\hline 7 & Tertabrak kendaraan & $\mathbf{0}$ \\
\hline $\mathbf{8}$ & Terpeleset atau terkilir & $\mathbf{2}$ \\
\hline \multicolumn{2}{|c}{ TOTAL } \\
\hline
\end{tabular}

Dari data jenis kecelakaan kerja tersebut, kecelakaan kerja yang paling dominan adalah terkena cutter, sebanyak 24 kejadian yang terjadi selama kurun waktu tiga tahun.

Langkah kedua dari pembuatan Job Safety Analysis adalah memecah pekerjaan atas beberapa langkah kerja atau menguraikan satu persatu berdasarkan urutan proses kerja dari aktivitas tersebut. Pekerjaan yang menjadi sasaran yaitu pada penerimaan afval lokal bagian warehouse. Penerimaan afval lokal bagian warehouse merupakan salah satu bagian yang menerima material sebagai bahan baku produk kertas.

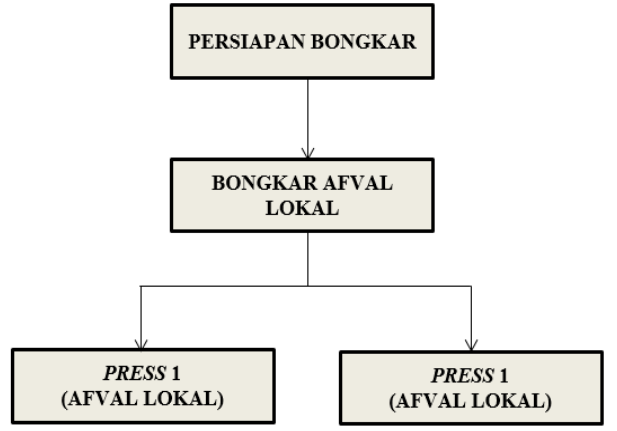

Gambar 1. Proses penerimaan afval lokal

Dengan uraian pekerjaan sebagai berikut:

1. Persiapan bongkar

Dalam proses ini yang pertama dilakukan oleh pekerja adalah memepersiapkan area bongkar yang digunakan untuk membongkar kendaraan afval lokal menurut jenis kertasnya. Tahapannya yaitu :
a. Membuat pagar pembatas
b. Bersihkan area bongkar
c. Parkirkan kendaraan
d. Membuka terpal kendaraan 
Tabel 3. Potensi bahaya pada penerimaan afval lokal

\begin{tabular}{|c|c|c|}
\hline No. & Tahapan Kerja & Potensi Bahaya \\
\hline \multirow[t]{2}{*}{1} & Persiapan bongkar & \\
\hline & $\begin{array}{l}\text { * Membuat pagar pembatas } \\
\text { * Bersihkan area bongkar } \\
\text { * Parkirkan kendaraan } \\
\text { * Membuka terpal kendaraan } \\
\text { * Mengecek surat jalan dan memasukkan data sebelum } \\
\text { proses bongkar }\end{array}$ & $\begin{array}{l}\text { * Tertimpah bal - balan kertas } \\
{ }^{*} \text { Terjepit oleh bal - balan kertas } \\
\text { * Tertabrak kendaraan }\end{array}$ \\
\hline \multirow[t]{2}{*}{2} & Bongkar afval local & \\
\hline & $\begin{array}{l}\text { * Naik dan mengecek muatan kendaraan afval } \\
\text { * Mengangkat dan menggeser bal - balan kertas } \\
\text { * Memegang dan mnotong tali bal - balan kertas } \\
\text { * Mendorong bal- balan kertas ke lantai } \\
\text { * Selasai bongkar, memasukkan data potongan }\end{array}$ & $\begin{array}{l}\text { * Terjatuh dari atas kendaraan } \\
* \text { Tertimpah bal - balan kertas } \\
\text { * Terjepit oleh bal - balan kertas } \\
\text { * Terjepit tali bal - balan } \\
{ }^{*} \text { Terkena cutter } \\
\text { * Terkena plat atau kawat } \\
\text { * Terpeleset atau terkilir }\end{array}$ \\
\hline \multirow[t]{2}{*}{3} & Press afval local & \\
\hline & $\begin{array}{l}\text { * Jalankan mesin bal press } \\
\text { * Mendorong lasahan afval ke mesin dengan kendaraan } \\
\text { loader } \\
\text { * Mengangkat hasil bal press dengan kendaraan forklif untuk } \\
\text { ditimbang } \\
\text { * Menumpuk dan menata bal press } \\
\text { * Matikan mesin waktu istirahat dan selesai kerja }\end{array}$ & $\begin{array}{l}{ }^{*} \text { Terjepit oleh bal - balan kertas } \\
{ }^{*} \text { Tertabrak kendaraan }\end{array}$ \\
\hline
\end{tabular}

e. Mengecek surat jalan dan memasukkan data sebelum proses bongkar

2. Bongkar afval lokal

Setelah persiapan bongkar kemudian pekerja melakukan pembongkaran afval lokal. Tahapannya yaitu :

a. Naik dan mengecek muatan kendaraan afval

b. Mengangkat dan menggeser bal-balan kertas

c. Memegang dan memotong tali bal-balan kertas

d. Mendorong bal-balan kertas ke lantai

e. Selesai bongkar, memasukkan data potongan

Keterangan : Tali bal-balan kertas berupa tali rafia, nilon, kawat dan plat.

3. Press afval lokal

Kemudian pekerja menjalankan unit mesin press kertas yang berfungsi untuk membuat bal press (bal-balan kertas) serta aktivitas-aktivitas pekerja lain dalam melakukan pemindahan bal press dari mesin press ke alat timbang. Adapun mesin press yang terdapat pada penerimaan afval lokal ini ada 2 mesin press, namun mempunyai spesifikasi yang sama dan tujuannya agar lebih efisien. Tahapannya yaitu :

a. Jalankan mesin bal press

b. Mendorong lasahan afval ke mesin dengan kendaraan loader

c. Mengangkat hasil bal press dengan kendaraan forklif untuk ditimbang

d. Menumpuk dan menata bal press

e. Matikan mesin waktu istirahat dan selesai kerja

Langkah ketiga dalam job safety analysis adalah mengidentifikasi bahaya atau kecelakaan kerja yang dominan pada masing-masing proses. Potensi bahaya pada penerimaan afval lokal dapat terjadi mulai dari awal proses hingga akhir proses.
Identifikasi potensi bahaya merupakan alat manajemen untuk mengendalikan kerugian dan bersifat proaktif dalam upaya pengendalian bahaya di lapangan/tempat kerja. Untuk melakukan identifikasi yang efektif, diperlukan hal-hal seperti dibawah ini :

1. Melakukan pengamatan secara dekat.

2. Mengetahui hal-hal yang berhubungan dengan pekerjaan yang diamati.

3. Pengamatan dilakukan secara berulang-ulang.

4. Melakukan dialog dengan operator yang dinilai berpengalaman dalam pekerjaan yang diamati.

Pada Tabel 3 adalah tabel potensi bahaya atau kecelakaan kerja yang terdapat pada penerimaan afval lokal. Dari data potensi bahaya pada Tabel 3, dapat digambarkan dalam bentuk diagram sebab akibat (diagram ishikawa) seperti Gambar 2.

Dari hasil pengamatan yang telah dilakukan, maka dapat diketahui hasil tingkat kecelakaan kerja selama periode 3 tahun dari tahun 2013 sampai tahun 2015 pada penerimaan afval lokal sebagai berikut:

1. Tahun 2013

Perhitungan angka frekuensi kecelakaan $(F)$, yaitu banyaknya kecelakaan untuk setiap juta jam kerja orang:

Frekuensi kecelakaan kerja (FR)

$$
\begin{aligned}
& =\frac{\text { Banyaknya kecelakaan } \times 1.000 .000}{\text { Jam kerja orang }} \\
& =\frac{18 \times 1.000 .000}{107746}=\frac{18.000 .000}{107746}=167.059566 \\
& =167.06
\end{aligned}
$$

Nilai $F R=167.06$, berarti bahwa pada periode tahun 2013 tersebut terjadi banyaknya 
kecelakaan kerja sebesar 167.06 per-sejuta orang kerja.

Angka beratnya kecelakaan $(S)$ adalah jumlah total hilangnya hari kerja per 1.000 .000 jam kerja. Jadi rumusnya sebagai berikut:

\section{Beratnya kecelakaan $(S R)$}

$$
\begin{aligned}
& =\frac{\text { Jumlah hilangnya jam kerja } \times 1.000 .000}{\text { Jam kerja orang }} \\
& =\frac{54 \times 1.000 .000}{107746}=\frac{54.000 .000}{107746}=501.178698 \\
& =501.18
\end{aligned}
$$

Nilai severity rate 501.18 mengindikasikan bahwa selama kurun waktu tahun 2013 telah terjadi hilangnya waktu kerja sebesar 501 hari per-sejuta jam kerja orang.

Angka frekuensi kecelakaan (FR) dan angka keparahan atau beratnya kecelakaan $(S R)$ dapat diubah menjadi satu indicator FSI (Frequency Severity Indicator) sebagaimana diterangkan di atas dengan rumus sebagai berikut:

$$
\begin{aligned}
& \text { Tingkat keadaan }(F S) \text { : } \\
& \quad=\frac{\text { Frequency Ratex } \text { Severity Rate }}{1000} \\
& \begin{aligned}
F S I & =\frac{167.06 \times 501.18}{1000}=\frac{83727.1308}{1000}=83.7271308 \\
& =83.73
\end{aligned}
\end{aligned}
$$

2. Tahun 2014

$$
\begin{aligned}
F R & =\frac{\text { Banyaknya kecelakaan } \times 1.000 .000}{\text { Jam kerja orang }} \\
& =\frac{12 \times 1.000 .000}{109590}=109.499042 \\
& =109.5
\end{aligned}
$$

Nilai $F R=109.5$ berarti, bahwa pada periode tahun 2014 tersebut terjadi banyaknya kecelakaan kerja sebesar 109.5 jam per-sejuta orang kerja.

\section{Beratnya kecelakaan $(S R)$}

$$
\begin{aligned}
& =\frac{\text { Jumlah hilangnya jam kerja } \times 1.000 .000}{\text { Jam kerja orang }} \\
& =\frac{25 \times 1.000 .000}{109590}=\frac{25.000 .000}{109590}=228.123004 \\
& =228.12
\end{aligned}
$$

Nilai severity rate 228.12 mengindikasikan bahwa selama kurun waktu 2014 telah terjadi hilangnya waktu kerja sebesar 228.12 hari persejuta jam kerja orang.

$$
\begin{aligned}
& \text { Tingkat keadaan }(F S I): \\
& =\frac{\text { Frequency Rate } x \text { Severity Rate }}{1000} \\
& \begin{aligned}
F S I & =\frac{109.5 \times 228.12}{1000}=\frac{24979.14}{1000}=24.97914 \\
& =24.98
\end{aligned}
\end{aligned}
$$

\section{Tahun 2015}

\begin{tabular}{|c|c|c|c|}
\hline No. & Tahapan Kerja & Potensi Bahaya & $\begin{array}{c}\text { Tindakan } \\
\text { Pengendalian }\end{array}$ \\
\hline \multirow[t]{2}{*}{1} & Persiapan bongkar & & \\
\hline & $\begin{array}{l}{ }^{*} \text { Membuat pagar pembatas } \\
\text { *Bersihkan area bongkar } \\
\text { *Parkirkan kendaraan } \\
{ }^{*} \text { Membuka terpal kendaraan } \\
{ }^{*} \text { Mengecek surat jalan dan memasukkan } \\
\text { data sebelum proses bongkar }\end{array}$ & $\begin{array}{l}{ }^{*} \text { Tertimpah bal - } \\
\text { balan kertas } \\
{ }^{*} \text { Terjepit oleh bal } \\
\text { - balan kertas } \\
{ }^{*} \text { Tertabrak } \\
\text { kendaraan }\end{array}$ & $\begin{array}{l}\text { * Baca / ikuti rambu - } \\
\text { rambu keselamatan } \\
{ }^{*} \text { Mengikuti briffing } \\
\text { sebelum kerja } \\
\text { * Mengikuti instruksi } \\
\text { kerja yang benar }\end{array}$ \\
\hline \multirow[t]{2}{*}{2} & Bongkar afval local & & \\
\hline & $\begin{array}{l}\text { *Naik dan mengecek muatan kendaraan } \\
\text { afval } \\
{ }^{*} \text { Mengangkat dan menggeser bal - balan } \\
\text { kertas } \\
{ }^{*} \text { Memegang dan memotong tali bal - balan } \\
\text { kertas } \\
{ }^{*} \text { Mendorong bal- balan kertas ke lantai } \\
\text { *Selasai bongkar, memasukkan data } \\
\text { potongan }\end{array}$ & $\begin{array}{l}\text { * Terjatuh dari } \\
\text { atas kendaraan } \\
\text { * Tertimpah bal - } \\
\text { balan kertas } \\
\text { *Terjepit oleh bal } \\
\text { - balan kertas } \\
\text { * Terjepit tali bal - } \\
\text { balan } \\
\text { * Terkena cutter } \\
\text { * Terkena plat } \\
\text { atau kawat } \\
\text { *Terpeleset atau } \\
\text { terkilir }\end{array}$ & $\begin{array}{l}\text { *Baca/ ikuti rambu - } \\
\text { rambu keselamatan } \\
\text { * Mengikuti briffing } \\
\text { sebelum kerja } \\
\text { *Mengikuti instruksi } \\
\text { kerja yang benar } \\
\text { *Gunakan sarung } \\
\text { tangan katun } \\
\text { *Gunakan sepatu }\end{array}$ \\
\hline \multirow[t]{2}{*}{3} & Press afval local & & \\
\hline & $\begin{array}{l}\text { *Jalankan mesin bal press } \\
\text { * Mendorong lasahan afval ke mesin } \\
\text { dengan kendaraan loader } \\
\text { * Mengangkat hasil bal press dengan } \\
\text { kendaraan forklif untuk ditimbang } \\
\text { * Menumpuk dan menata bal press } \\
\text { * Matikan mesin waktu istirahat dan } \\
\text { selesai kerja }\end{array}$ & $\begin{array}{l}\text { * Terjepit oleh bal } \\
\text { - balan kertas } \\
{ }^{*} \text { Tertabrak } \\
\text { kendaraan }\end{array}$ & $\begin{array}{l}\text { * Baca / ikuti rambu - } \\
\text { rambu keselamatan } \\
{ }^{*} \text { Mengikuti briffing } \\
\text { sebelum kerja } \\
\text { * Mengikuti instruksi } \\
\text { kerja yang benar }\end{array}$ \\
\hline
\end{tabular}

$$
F R=\frac{\text { Banyaknya kecelakaan } \times 1.000 .000}{\text { Jam kerja orang }}
$$

$$
\begin{aligned}
& =\frac{12 \times 1.000 .000}{107520}=65.1041667 \\
& =65.1
\end{aligned}
$$

Nilai $F R=65.1$ berarti, bahwa pada periode tahun 2015 tersebut terjadi banyaknya kecelakaan kerja sebesar 65.1 jam per-sejuta orang kerja.

\section{Beratnya kecelakaan $(S R)$}

$$
\begin{aligned}
& =\frac{\text { Jumlah hilangnya jam kerja } \times \mathbf{1 . 0 0 0 . 0 0 0}}{\text { Jam kerja orang }} \\
& =\frac{5 \times 1.000 .000}{107520}=\frac{5.000 .000}{107520}=46.5029762 \\
& =46.5
\end{aligned}
$$

Nilai severity rate 46.5 mengindikasikan bahwa selama kurun waktu tahun 2015 telah terjadi hilangnya waktu kerja sebesar 46.5 hari persejuta jam kerja orang.

Tingkat keadaan (FSI)

$$
\begin{aligned}
& =\frac{\text { Frequency Rate } x \text { Severity Rate }}{1000} \\
F S I & =\frac{65.1 \times 46.5}{1000}=\frac{3027.15}{1000}=3.02715 \\
& =3.03
\end{aligned}
$$

Tabel 4. Tindakan pengendalian pada penerimaan afval lokal

Langkah keempat adalah tahap akhir dari JSA yang merupakan upaya pencegahan kecelakaan setelah semua jenis kecelakaan telah diidentifikasi dari setiap langkah pekerjaan. Secara umum tindakan pengendalian kecelakaan kerja yang dilaksanakan oleh karyawan pada penerimaan afval lokal bagian warehouse dilakukan dengan cara sebagai berikut :

1. Baca/ikuti rambu-rambu keselamatan. 


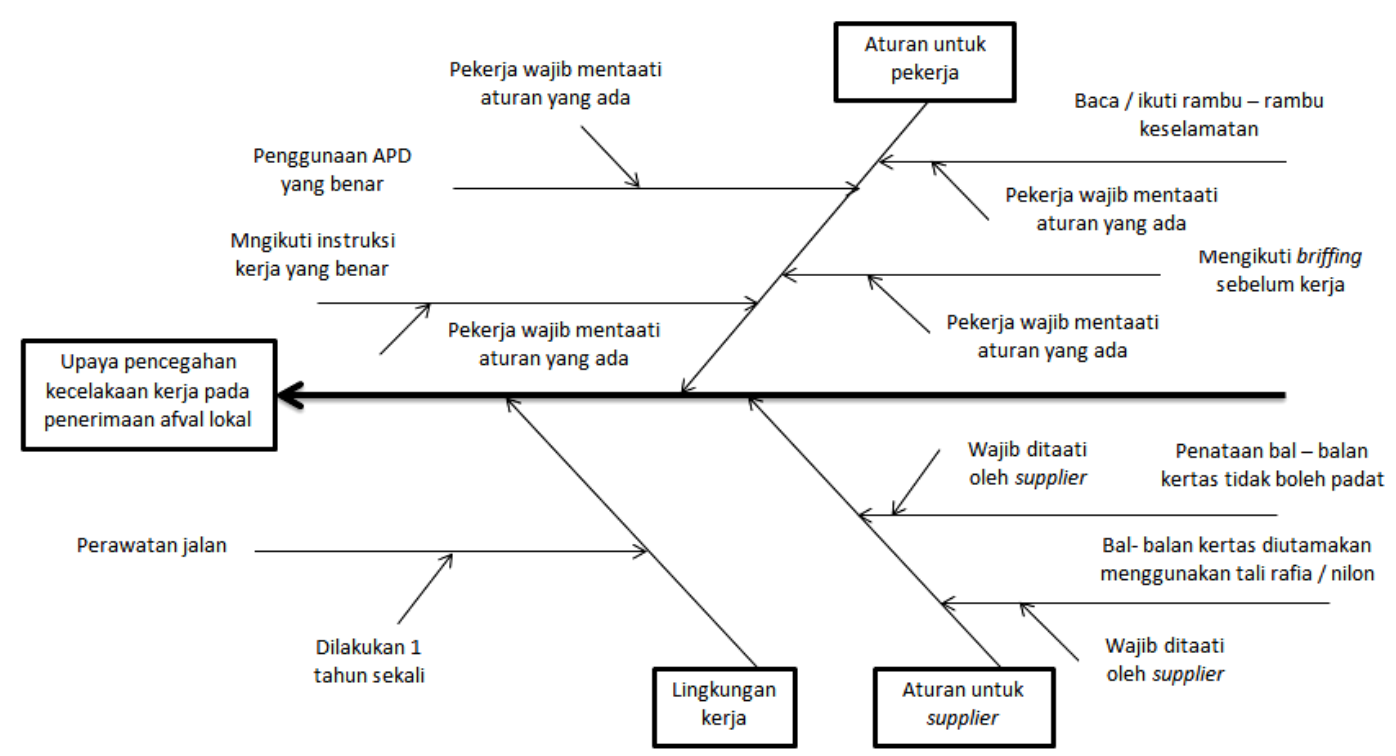

Gambar 3. Diagram sebab dan akibat upaya pencegahan pada penerimaan afval lokal

2. Mengikuti briffing sebelum kerja.

3. Mengikuti instruksi kerja yang benar.

4. Gunakan Alat Pelindung Diri (APD) yang benar seperti : masker, sarung tangan katun dan sepatu.

Berikut ini adalah tindakan pengendalian kecelakaan kerja yang dibuat oleh Kasi/Wakasi dan disetujui oleh Kabag/Wakabag bagian warehouse yang meliputi tindakan-tindakan/prosedur untuk mengurangi kecelakaan kerja pada setiap langkah pekerjaan, seperti tampak pada Tabel 4 .

Dari data tindakan pengendalian di atas dapat digambarkan dalam bentuk diagram sebab akibat (diagram ishikawa) seperti Gambar 3.

\section{PENUTUP}

Dengan metode JSA (Job Safety Analysis) dapat diidentifikasi jenis kecelakaan kerja/potensi bahaya yang berhubungan dari setiap langkah pekerjaan pada penerimaan afval local, yaitu: terjatuh dari atas kendaraan, tertimpa dan terjepit oleh bal-balan kertas, terjepit tali bal-balan, terkena cutter, terkena plat atau kawat, tertabrak kendaraan, serta terpeleset atau terkilir.

Jenis kecelakaan kerja yang dominan pada penerimaan afval lokal adalah terkena cutter dengan 24 kali kejadian yang terjadi pada penerimaan afval lokal selama 3 tahun periode tahun 2013-2015.

Dari perhitungan nilai FR, SR, serta nilai FSI untuk periode tahun 2013-2015, dapat diketahui tingkat kecelakaan kerja (FSI) dari tahun 2013 sampai tahun 2015 adalah sebesar 83.73, 24.98, dan 3.03, yang menunjukkan hasil yang semakin menurun, yang berarti kinerja pada penerimaan afval lokal semakin baik.
Upaya untuk pencegahan kecelakaan kerja pada penerimaan afval lokal dapat dilakukan dengan cara: baca/ikuti rambu-rambu keselamatan kerja, mengikuti briffing sebelum kerja, mengikuti instruksi kerja yang benar, gunakan sarung tangan katun, serta gunakan sepatu.

\section{DAFTAR PUSTAKA}

Alkon. (2004). Teknik Manajemen Resik. Surabaya : PT. Alkon Trainindo Utama.

Ashfal, C., Ray. (1999). Industrial Safety And Health Management. Fourth Edition. New Jersey : Prentice-Hall, Inc.

Chevron. (2005). Modul 06-SOP dan JSA. Jakarta : PT. Cevron Pacific Indonesia.

KI, (2012). Kamus Industri, Job Safety Analysis (JSA), http://kamusindustri.blogspot.com /2012/04/-jsa-job-safety-analysis.html, online, 16 Juni 2015.

Prabowo, K. H. (2005). Pengukuran Tingkat Kinerja Implementasi Lingkungan, Kesehatan, dan Keselamatan Kerja (LK3) dan Perangkingan Hazards dengan Pendekatan Risk Assessment. Surabaya : (studi kasus: Instalasi Surabaya Grup-Unit Pemasaran V Pertamina Surabaya), Tugas Akhir. Surabaya : Teknik Industri ITS.

Pramono, W. A. (2015). Job Safety Analysis (JSA), http://www.wishnuap.com/2012/02/jobsafety-analysis-jsa.html, online , 16 Juni 2015.

Suma'mur. (1996). Keselamatan Kerja Dan Pencegahan Kecelakaan. Jakarta : CV. Haji Masagung.

Zalaya, dan Zulkarnaen. (2015). Job Safety Analysis (JSA), http://safetytrainingindonesia. blogspot.com/2010/06/job-safety-analysisjsa.html , online, 16 Juni 2015. 